experimentation would prove, although there is confusion in his mind between irritability and elasticity of tissues. The statement that Haller denied "any relationship between sensibility and irritability" (page 70) is a mis. representation. The continuity between the two was maintained by the "nervous fluid", the same in sensation and in motion, and Marshall Hall considered Haller's vis nervosa to be the cause of reflex action. To this example of the repercussion of the controversy in the 19th century, may be added Claude Bernard's: "our opinion is definitely established; we are for Haller and against Whytt".

Another point of dispute was the significance of glue as the structure underlying irritability. This was not only Haller's opinion and for almost a century glue was considered as the animal substanco, even in plants, and irritability characteristic of animality its functional counterpart. The idea of zoophyte (animal-plant) and the experiments initiated by Trembley on polyps, were arguments used in its favour.

Epithets designating philosophical opinions were commonplace and Haller could see no difference between Whytt's and Stahl's animism. (Leibniz accused Stahl of materialism.) Nor was Haller a materialist as Whytt thought. Their time witnessed the dawn of vitalism, not the metaphysical vitalism of the unifying vital force, but that of vital properties to which Haller contributed and which was beneficial to the development of physiology. One common feature emerges from the dispute between mechanists, animists and vitalists: they were all mechan ists in their experimental procedures. As a result, Whytt's definition of the reflex is less surprising than it first appears (page 91 ).

To those problems French contributes an important book with over 400 bibliographical references. The hope of turning his thesis into "a readable book", is fully fulfilled. Chapters like "The problem of the seat of the soul" and "The ventricular theory" are a major source of information on the history of the soul. J. SCHILLER

\section{MORGAN CENTENARY}

\section{Genetics and Developmental Biology}

Edited by Howard J. Teas. (The Thomas Hunt Morgan

Centennial Symposium.) Pp. viii + 164. (University of Kentucky Press: Lexington, May 1969.) \$6.50.

T. H. Morgan was born at Lexington, Kentucky, on September 25, 1866. By a coincidence, this was the year of publication of Mendel's great contribution to biology, to which 50 years later Morgan and associates were to add so notably. A symposium on genetics and developmental biology was held at Lexington on the centenary of Morgan's birth. 'This book contains ten of the contributions and also, in an introduction, some brief recollections of the man by A. H. Sturterant, 'T. Mohr, A. Tyler and $G$. Beadle.

Reports of symposia are often of limited value because the contributions are usually published in journals about the same time as the meeting. In the present instance, 3 years have elapsed since the papers were given, so it is not surprising that virtually all the material in the book has already been published elsewhere. Two of the contributions-by P. Howard-Flander's on genotic repair mechanisms, and by W. B. Wood on bacteriophage morphogenesis-have been largely rewritten, however, to bring them up to date; these articles are authoritative and of great interest. They contain such ideas as recombination as a means of constructing undarnaged DNA molecules from damaged ones, and phage assembly as a scries of steps the sequence of which is imposed. not by the order in which particular genes function, but by the way in which their products interact. It is appropriate that J. H. Taylor has contributed to the volume because the remarkable discoveries about chromosome structure and behaviour which he and his colleagues have made. using autoradiographic and other techniques, relate directly to Morgan's work. Taylor reviews his own findings, including the evidence that crossing-over-a term invented by Morgan-involves breakage of DNA molecules and their reunion in new ways. There is also a discussion by N. Sueoka and associates of their studies with Chlamydomonas which lead to similar conclusions. J. Bonner discusses the control of gene activity, A. Tyler the masking of messenger RNA in embryonic development, W. E. Barnett and colleagues the unique transfer RNAs associated with mitochondria and $R$. Haselkorn the suppression of phage mutants by a mutant transfer RNA. A contribution by T. S. Matney and J. C. Suit on chromosome transfer in bacterial mating and one by K. G. Lark on non-random segregation of sister chromatids are more controversial. Each paper in the volume concludes with a reference list, those of Howard-Flanders and Tyler being quite extensive.

The editing of the publication has not been altogether satisfactory: there is no index, several words are misspelt and there is a lack of uniformity in the abbreviations adopted for transfer RNA and for some journals. The discussion following two of the papers appears verbatim and includes such trivialities as a slip of the tongue and its correction!

One might ask to whom this volume is addressed. Its subject-matter is so diverse that the reader cannot begin to obtain an overall picture of the irmmense fields of knowledge in the title. Many of the fragments of the picture which are revealed do not now give an up to date representation, and to purchase the book for the sake of those that do is prohibitively costly. One is left with the feeling that better justice would have been done to the memory of a great man if the symposium had concentrated on a narrower field and if publication had been immediate.

\section{H. L. K. Whitehotse}

\title{
BETTER VICTUALS
}

\section{Protein-Enriched Cereal Foods for World Needs}

Edited by Max Milner. Pp. $x+343$. (The American Association of Cereal Chemists: St Paul, Minnesota, 1969.) $\$ 7.50$.

In May 1968, the American Association of Cereal Chemists and the American Oil Chemists' Society organized a meeting to consider world food supplies. 'The papers given at the meeting are printed here along with some supplementary material intended to put them into perspective. Up to date estimates, compiled by $\mathrm{FAO}$ and the US Department of Agriculture, are given of the amounts of different foodstuffs eaten in different countries; these show that cereals are the principal protein source. Abbott. from $\mathrm{FAO}$, analyses these figures further and compares people living in rural and urban regions of the same country. Where little anımal protein is eaten, most of it is eaten in the towns. This is a point that should be remembered when methods of enrichment are being considered, for the enriched products are also likely to be eaten chiefly in towns. The article is marred by some guesses at the probable costs of various novel protein sources; if the fatuous figure given for loaf protein is typical, these ar not of much value.

When people from Europe and North America consider the use of any form of food supplement, the first suggestion thoy are likely to make is that the supplement should be added to bread. In accordance with this tradition. several papers deal with bread and with the fortification of wheat flour with lysine, soya, cotton-seed, quinoa seed. rice bran and fish flour. Bread making without flour is 